\title{
Dammarane-Type Glycosides from the Steamed Flower-Buds of Panax ginseng
}

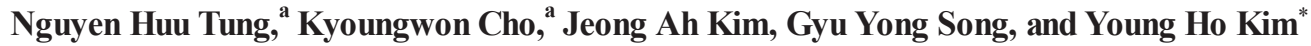 \\ College of Pharmacy, Chungnam National University, Daejeon 305-764, Korea. *E-mail: yhk@cnu.ac.kr \\ Received January 23, 2010, Accepted March 3, 2010
}

Key Words: Panax ginseng, Araliaceae, Ginsenosides SF, Dammarane-type triterpene

Panax ginseng C.A. Meyer (Araliaceae), an ancient and famous herbal drug in oriental traditional medicine, has been used as a tonic and for the treatment of various diseases., ${ }^{1,2}$ Biologically active constituents of whole parts of $P$. ginseng (roots, leaves, flower buds, and fruits) have been pursued extensively and many dammarane-type triterpene oligoglycosides have been characterized as the principal components. ${ }^{1-4}$

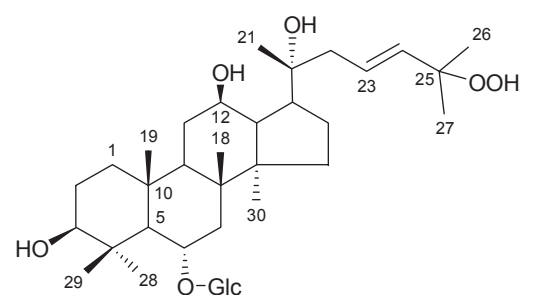

Figure 1. Ginsenoside SF (1).<smiles></smiles>

3, R $=$ Glc
9, $R=G l c-2-R h a$
Extracts from roots and flower buds have similar multifaceted pharmacological activities (e.g. central nervous system). ${ }^{5}$ Traditionally, the root of $P$. ginseng (ginseng), the most used and valuable part, has been processed to make white ginseng (WG, roots air-dried after peeling) and red ginseng ( $\mathrm{RG}$, roots steamed at $98 \sim 100{ }^{\circ} \mathrm{C}$ without peeling) to enhance its preservation and efficacy. $\mathrm{RG}$ is more common as an herbal medicine than WG, because steaming induces changes in the chemical constituents and enhances the biological activities of ginseng. Moreover, there has been no study on chemical components from processed flower-buds of this plant to date. Subsequently, in continuation of our research on $P$. ginseng, ${ }^{6,7}$ the present study on chemical components of the steamed flower-buds led to the isolation of one new damarane-type saponin, named ginsenoside SF (1) (Fig. 1), and nineteen known saponins (2-20) (Fig. 2), including ginsenoside $\mathrm{Rh}_{4}(\mathbf{2}){ }^{8}$ ginsenoside $\mathrm{Rk}_{3}(\mathbf{3}){ }^{8}$, ginsenoside $\mathrm{F}_{1}(\mathbf{4}),{ }^{9}(20 E)$-ginsenoside $\mathrm{F}_{4}(\mathbf{5}),{ }^{10}$ ginsenoside $\operatorname{Rg}_{2}(\mathbf{6}),{ }^{11}$

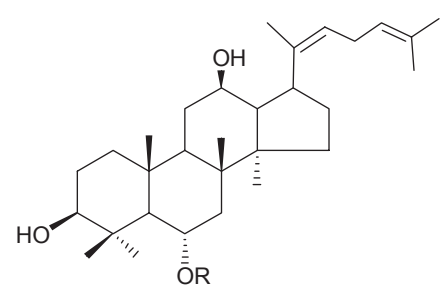

2, $\mathrm{R}=\mathrm{Glc}$
8, R $=\mathrm{Glc} \stackrel{2}{-} \mathrm{Rha}$

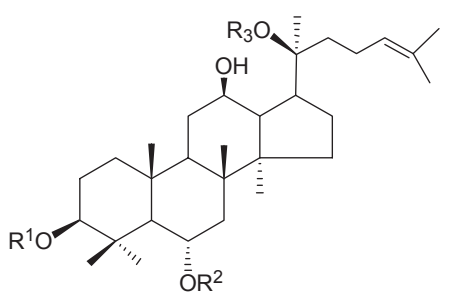

4, $\mathrm{R}^{1}=\mathrm{R}^{2}=\mathrm{H} ; \mathrm{R}^{3}=\mathrm{Glc}$

6, $\mathrm{R}^{1}=\mathrm{R}^{3}=\mathrm{H} ; \mathrm{R}^{2}=\mathrm{Glc} \stackrel{2}{2} \mathrm{Rha}$

10, $\mathrm{R}^{1}=\mathrm{H} ; \mathrm{R}^{2}=\mathrm{R}^{3}=\mathrm{Glc}$

11, $R^{1}=H ; R^{2}=G l c \frac{2}{2} R h a ; R^{3}=G l c \frac{6}{-} A c$

$15, R^{1}=H ; R^{2}=G l c \stackrel{2}{-} R h a ; R^{3}=G l c$

16, $R^{1}=G l c \stackrel{2}{-} G l c ; R^{2}=H ; R^{3}=G l c$

20, $R^{1}=R^{2}=H ; R^{3}=G l c \stackrel{6}{-} A c$

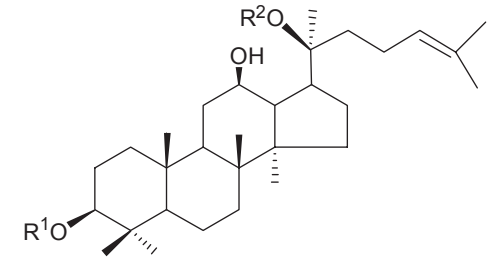

7, $R^{1}=\mathrm{Glc} \frac{2}{2} \mathrm{Glc} \frac{6}{-} \mathrm{Ac} ; \mathrm{R}^{2}=\mathrm{Glc}$

12, $R^{1}=\mathrm{Glc} \frac{2}{2} \mathrm{Glc} ; \mathrm{R}^{2}=\mathrm{Glc}$

13, $R^{1}=\mathrm{Glc}-\frac{2}{2} \mathrm{Glc} ; \mathrm{R}^{2}=\mathrm{Glc}-6$ Ara(f)

14, $R^{1}=\mathrm{Glc} \stackrel{2}{-} \mathrm{Glc} ; \mathrm{R}^{2}=\mathrm{Glc} \stackrel{6}{-} \mathrm{Ara}(\mathrm{p})$

17, $R^{1}=G l c ; R^{2}=G l c \stackrel{6}{-} A r a(p)$

18, $R^{1}=\mathrm{Glc} \stackrel{2}{-} \mathrm{Glc} ; \mathrm{R}^{2}=\mathrm{Glc} \stackrel{6}{-} \mathrm{Glc}$

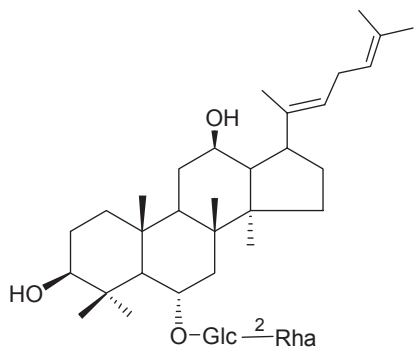

5<smiles>CC(C)=CC/C=C(/C)C1CC[C@]2(C)C1C(O)CC1[C@@]3(C)CCC(O[Ge]4CCCCC4)C(C)(C)C3CC[C@]12C</smiles>

19

Ac: acetyl

Glc: $\beta$-D-glucopyranosyl

Ara(p): $\alpha$-L-arabinopyranosyl

Ara(f): $\alpha$-L-arabinofuranosyl

Rha: $\alpha$-L-rhamnopyranosyl

Figure 2. Structures of known saponins 2-20.

${ }^{\mathrm{a}}$ These authors contributed equally to this work. 


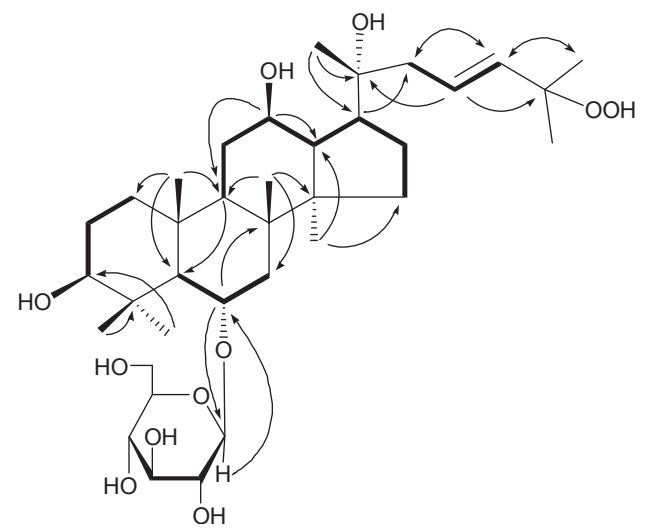

Figure 3. COSY (bold lines), selected HMBC Correlations (arrows) of ginsenoside SF (1).

pseudoginsenoside $\mathrm{RC}_{1}(\mathbf{7}){ }^{4}$ ginsenoside $\operatorname{Rg}_{6}(\mathbf{8}),{ }^{12}$ ginsenoside $\mathrm{F}_{4}(\mathbf{9}),{ }^{12}$ ginsenoside $\operatorname{Rg}_{1}(\mathbf{1 0}),{ }^{13} 6$-acetyl-ginsenoside $\operatorname{Rg}_{1}(\mathbf{1 1}),{ }^{14}$ ginsenoside Rd (12), ${ }^{6}$ ginsenoside Rc (13), ${ }^{6}$ ginsenoside $\mathrm{Rb}_{2}$ (14), ${ }^{6}$ ginsenoside $\operatorname{Re}(\mathbf{1 5}),{ }^{6}$ vinaginsenoside $\mathrm{R}_{4}(\mathbf{1 6}){ }^{6}$, ginsenoside $\mathrm{Mb}(\mathbf{1 7}),{ }^{15}$ ginsenoside $\mathrm{Rb}_{1}(\mathbf{1 8}),{ }^{6}$ ginsenoside $\mathrm{Rs}_{4}(\mathbf{1 9}),{ }^{16}$ and 6'-acetyl-ginsenoside $\mathrm{F}_{1}(\mathbf{2 0}),{ }^{14}$ respectively, on the basis of NMR, ESI-MS data, and comparison with those reported in the literature.

Ginsenoside SF (1), an amorphous powder, has the molecular formula $\mathrm{C}_{36} \mathrm{H}_{62} \mathrm{O}_{11}$ as deduced by a high-resolusion electrospray-ionization time-of-flight mass spectrometry (HRESITOFMS) experiment (found at $m / z[\mathrm{M}+\mathrm{Na}]^{+}$693.4141, calcd. for $\mathrm{C}_{36} \mathrm{H}_{62} \mathrm{O}_{11} \mathrm{Na}$ 693.4190). Acid hydrolysis of 1 liberated D-glucose as confirmed by gas chromatography (GC) analysis. It was proposed to possess a hydroperoxyl group due to positive response to $N, N$-dimethyl- $p$-phenylenediammonium dichloride. ${ }^{4,5}$ The ${ }^{1} \mathrm{H}-\mathrm{NMR}$ spectrum of $\mathbf{1}$ showed signals due to the aglycone part $[\delta 0.88,1.07,1.25,1.43,1.56,1.57,1.65,2.09$ (3H each, all s, $\left.\mathrm{H}_{3}-30,19,18,21,26,27,29,28\right), 3.54$ (1H, dd, $J=11.6,4.8 \mathrm{~Hz}, \mathrm{H}-3), 3.98$ (1H, m, H-12), 4.42 (1H, m, H-6), $6.08(1 \mathrm{H}, \mathrm{d}, J=16.0 \mathrm{~Hz}, \mathrm{H}-24)$, and $6.38(1 \mathrm{H}, \mathrm{m}, \mathrm{H}-23)]$ and an anomeric proton at $\delta 5.07\left(\mathrm{~d}, J=7.2 \mathrm{~Hz}, \mathrm{H}-1^{\prime}\right)$, which was assignable to a $\beta$-glucopranosyl unit. The ${ }^{13} \mathrm{C}$-NMR spectrum of 1 exhibited 36 signals including a set of six signals $(\delta 106.0$, $75.4,79.6,71.8,78.2$, and 63.0) revealing a $\beta$-D-glucopyranosyl unit and 30 remaining ones of a sapogenol moiety. The signal of C-5 at $\delta 61.4$ is a feature of a protopanaxatriol-type aglycone, which is common among dammarane-type saponins in $P$. ginseng with variations in its side-chain. Furthermore, the ${ }^{1} \mathrm{H}$ - and ${ }^{13} \mathrm{C}$-NMR data of 1 were similar to those of $(20 R)$-ginsenoside $\mathrm{Rh}_{1}{ }^{17,18}$ except for the signals of the side-chain part $(\mathrm{C}-22 \sim$ $\mathrm{C}-27)$ resembling those of floralquinquenosides $\mathrm{A}$ and $\mathrm{C}$. ${ }^{19}$ $20 R$-Configuration was suggested based on the ${ }^{13} \mathrm{C}$-NMR evidence of $\mathrm{C}-17$ at $\delta 51.1$ and $\mathrm{C}-21$ at $\delta 22.7$, which were compatible with those of related structures. ${ }^{17,18}$ Accordingly, compound 1 was found to be the $20 R$-epimer of floralquinquenoside A. The proposed structure of $\mathbf{1}$ was further confirmed by the ${ }^{1} \mathrm{H}-{ }^{1} \mathrm{H}$ correlation spectroscopy (COSY) and heteronuclear multiple bond correlation (HMBC) spectra, respectively. As shown in Fig. 3, the ${ }^{1} \mathrm{H}-{ }^{1} \mathrm{H}$ COSY experiment on $\mathbf{1}$ indicated the presence of partial structures written in bold lines; and in the HMBC spectrum, the long-range correlations were observed between the following protons and carbons: H-6 and C-8; H-12 and C-9, 17; H-18 and C-7,9,14; $\mathrm{H}-19$ and C-1,5,9; H-21 and C-17; H-23 and C-20,25; H-24 and C-22,26; H-26 and C-24; H-1' and C-6. Consequently, the structure of ginsenoside SF (1) was characterized as (20R)-25-hydroperoxyl-3 $\beta, 6 \alpha, 12 \beta, 20 \alpha$-tetrahydroxy-dammar-23-ene 6-O- $\beta$-D-glucopyranoside.

On the basis of oriental medicine, the herbs need processing for different purposes. Like roots of $P$. ginseng, ${ }^{20-22}$ chemical compositions of the steamed flower-buds were significantly different from those of the raw materials. Because steaming was carried out under high temperature, new monodesmosides should be formed by chemical degradation of the C-20 glycosyl moiety of the dammarane skeleton during the processing. ${ }^{10,12} \mathrm{It}$ is apparent that rich dammarane-type monodesmosides presented are not only chemically characteristic of the steamed flower buds but also give special biological activities to this processed herb. To the best of our knowledge, this is the first report on chemical components of the steamed flower-buds of $P$. ginseng. The pharmaceutical evaluation of the steamed flowers is now in progress.

\section{Experimental}

General procedures. Optical rotations were obtained using a DIP-360 digital polarimeter (Jasco, Easton, MD). IR spectra were measured using a Perkin-Elmer 577 spectrometer (Perkin Elmer, Waltham, MA). NMR spectra were recorded on Bruker DRX 400 and 500 NMR spectrometers (Bruker, Billerica, MA). ESI-MS spectra were recorded on a Model 1100 LC-MSD Trap spectrometer (Agilent, Santa Clara, CA). HRESITOFMS measurements utilized a JEOL AccuTOF ${ }^{\mathrm{TM}}$ LC mass spectrometer (Jeol, Tokyo, Japan). GC (Shimadzu-2010, Tokyo, Japan) using a DB-05 capillary column $(0.5 \mathrm{~mm}$ i.d. $\times 30 \mathrm{~m})$ [column temperature: $210{ }^{\circ} \mathrm{C}$; detector temperature: $300{ }^{\circ} \mathrm{C}$; injector temperature: $270{ }^{\circ} \mathrm{C}$; He gas flow rate: $30 \mathrm{~mL} / \mathrm{min}$ (splitting ratio: $1 / 20)]$ was used for sugar determination. Column chromatography was performed on silica gel (70 - 230 and 230 - 400 mesh, Merck), YMC RP-18 resins (30 - $50 \mu \mathrm{m}$, Fuji Silysia Chemical Ltd., Aichi, Japan), and HP-20 Diaion (Mitsubishi Chemical, Tokyo, Japan). TLC was performed on Kieselgel $60 \mathrm{~F}_{254}$ (1.05715; Merck, Darmstadt, Germany) or RP-18 $\mathrm{F}_{254 \mathrm{~s}}$ (Merck) plates. Spots were visualized by spraying with $10 \%$ aqueous $\mathrm{H}_{2} \mathrm{SO}_{4}$ solution, followed by heating.

Plant material. The flower buds of $P$. ginseng were collected in Geumsan province, which is well-known for ginseng cultivation in Korea, in August 2008, and were taxonomically identified by one of us (Young Ho Kim). Voucher specimens (CNU 08202) have been deposited at the College of Pharmacy, Chungnam National University. The air-dried sample $(2.7 \mathrm{~kg})$ was then steamed at $120^{\circ} \mathrm{C}$ for $4 \mathrm{~h}$ under $0.15 \mathrm{MPa}$ pressure, without mixing with water, to give the steamed sample, which was used for extraction and isolation in this study.

Extraction and isolation. The steamed-flowers sample was extracted in $\mathrm{MeOH}\left(5.0 \mathrm{~L} \times 3,50^{\circ} \mathrm{C}\right)$ and the combined extracts were concentrated in vacuo to dryness. The $\mathrm{MeOH}$ residue (850 g) was suspended in $\mathrm{H}_{2} \mathrm{O}(2.5 \mathrm{~L})$, then partitioned with $\mathrm{CH}_{2} \mathrm{Cl}_{2}(2.5 \mathrm{~L} \times 3)$, and the water layer was subjected to a 
Table 1. ${ }^{1} \mathrm{H}$ - and ${ }^{13} \mathrm{C}-\mathrm{NMR}$ Data ${ }^{a}$ for Ginsenosides SF (1) in Pyridine- $d_{5}$

\begin{tabular}{|c|c|c|}
\hline Position & $\delta_{\mathrm{C}}$ & $\delta_{\mathrm{H}}(J$ in $\mathrm{Hz})$ \\
\hline 1 & 39.3 & $\begin{array}{l}1.03 \mathrm{~m} \\
1.73 \mathrm{~m}\end{array}$ \\
\hline 2 & 27.9 & $\begin{array}{l}1.87 \mathrm{~m} \\
1.95 \mathrm{~m}\end{array}$ \\
\hline 3 & 78.5 & $3.54 \mathrm{dd}(11.6,4.8)$ \\
\hline 4 & 40.4 & \\
\hline 5 & 61.4 & $1.42 \mathrm{~d}(8.0)$ \\
\hline 6 & 80.1 & $4.42 \mathrm{~m}$ \\
\hline 7 & 45.1 & $\begin{array}{l}1.97 \mathrm{~m} \\
2.54 \mathrm{~m}\end{array}$ \\
\hline 8 & 41.0 & \\
\hline 9 & 50.2 & $1.61 \mathrm{~m}$ \\
\hline 10 & 39.6 & \\
\hline 11 & 31.2 & $\begin{array}{l}1.46 \mathrm{~m} \\
2.13 \mathrm{~m}\end{array}$ \\
\hline 12 & 70.9 & $3.98 \mathrm{~m}$ \\
\hline 13 & 49.6 & $2.02 \mathrm{~m}$ \\
\hline 14 & 51.6 & \\
\hline 15 & 31.7 & $\begin{array}{l}1.10 \mathrm{~m} \\
1.61 \mathrm{~m}\end{array}$ \\
\hline 16 & 26.3 & $\begin{array}{l}1.29 \mathrm{~m} \\
1.85 \mathrm{~m}\end{array}$ \\
\hline 17 & 51.1 & $2.38 \mathrm{~m}$ \\
\hline 18 & 17.7 & $1.25 \mathrm{~s}$ \\
\hline 19 & 17.4 & $1.07 \mathrm{~s}$ \\
\hline 20 & 73.7 & \\
\hline 21 & 22.7 & $1.43 \mathrm{~s}$ \\
\hline 22 & 40.6 & $\begin{array}{l}2.16 \mathrm{~m} \\
2.56 \mathrm{~m}\end{array}$ \\
\hline 23 & 126.8 & $6.38 \mathrm{~m}$ \\
\hline 24 & 137.9 & $6.08 \mathrm{~d}(16.0)$ \\
\hline 25 & 81.3 & \\
\hline 26 & $25.3^{b}$ & $1.56 \mathrm{~s}$ \\
\hline 27 & $25.2^{b}$ & $1.57 \mathrm{~s}$ \\
\hline 28 & 31.7 & $2.09 \mathrm{~s}$ \\
\hline 29 & 16.4 & $1.65 \mathrm{~s}$ \\
\hline 30 & 17.3 & $0.88 \mathrm{~s}$ \\
\hline Glc-1' & 106.0 & $5.07 \mathrm{~d}(7.2)$ \\
\hline $2^{\prime}$ & 75.4 & $4.13 \mathrm{t}(8.0)$ \\
\hline $3^{\prime}$ & 79.6 & $4.28 \mathrm{t}(8.4)$ \\
\hline $4^{\prime}$ & 71.8 & $4.22 \mathrm{~m}$ \\
\hline $5^{\prime}$ & 78.2 & $3.97 \mathrm{~m}$ \\
\hline $6^{\prime}$ & 63.0 & $\begin{array}{l}4.40 \mathrm{~m} \\
4.57 \mathrm{br} \mathrm{d}(11.2)\end{array}$ \\
\hline
\end{tabular}

${ }^{a}$ Assignments were confirmed by COSY, HMQC, and HMBC spectra. ${ }^{b}$ Reversible.

Diaion HP-20 column eluted with a gradient of $\mathrm{MeOH}$ in $\mathrm{H}_{2} \mathrm{O}$ $(25,50,75$, and $100 \% \mathrm{MeOH} ; \mathrm{v} / \mathrm{v})$ to give six fractions (fr. $1.1 \sim$ fr. 1.6). Next, fr. $1.3(46 \mathrm{~g})$ was chromatographed on a silica gel column using $\mathrm{CH}_{2} \mathrm{Cl}_{2}-\mathrm{MeOH}$ (15:1 - 1:1) to afford nine subfractions (fr. $2.1 \sim$ fr. 2.9). Fr. $2.3(5.6 \mathrm{~g})$ was further chro- matographed on a silica gel column with $\mathrm{CHCl}_{3}-\mathrm{MeOH}-\mathrm{H}_{2} \mathrm{O}$ (7:1:0.1), followed by a reversed-phase (RP) column with $\mathrm{MeOH}-\mathrm{H}_{2} \mathrm{O}(2: 1)$ to obtain ginsenoside $\mathrm{Rh}_{4}(\mathbf{2}, 100 \mathrm{mg})$, ginsenoside $\mathrm{Rk}_{3}(3,110 \mathrm{mg})$, ginsenoside $\mathrm{F}_{1}(4,54 \mathrm{mg})$ and 6'acetyl-ginsenoside $\mathrm{F}_{1}(\mathbf{2 0}, 13 \mathrm{mg})$. Fr. $2.7(9.0 \mathrm{~g})$ was rechromatographed on a silica gel column with $\mathrm{CHCl}_{3}-\mathrm{MeOH}-\mathrm{H}_{2} \mathrm{O}$ (3:1:0.2) to afford eleven subfractions (fr. 3.1 fr. 3.11). Next, fr. $3.2(1.4 \mathrm{~g})$ was subjected to a RP column with $\mathrm{MeOH}-\mathrm{H}_{2} \mathrm{O}$ $(5: 2)$ to furnish (20E)-ginsenoside $\mathrm{F}_{4}(\mathbf{5}, 18 \mathrm{mg})$, ginsenoside $\operatorname{Rg}_{2}(6,35 \mathrm{mg})$, pseudoginsenoside $\mathrm{RC}_{1}(7,30 \mathrm{mg})$, ginsenoside $\operatorname{Rg}_{6}(\mathbf{8}, 40 \mathrm{mg})$, and ginsenoside $\mathrm{F}_{4}(\mathbf{9}, 36 \mathrm{mg})$. Similarly, fr. $3.5(1.1 \mathrm{~g})$ was repeatedly chromatographed on a RP column with $\mathrm{MeOH}-\mathrm{H}_{2} \mathrm{O}$ (3:1) to give ginsenoside $\mathrm{Rg}_{1}(\mathbf{1 0}, 114 \mathrm{mg})$, 6'-acetyl-ginsenoside $\operatorname{Rg}_{1}(\mathbf{1 1}, 118 \mathrm{mg})$, and ginsenoside $\operatorname{Rd}(\mathbf{1 2}$, $134 \mathrm{mg}$ ). Fr. $3.8(1.2 \mathrm{~g})$ was chromatographed on a RP column with $\mathrm{MeOH}-\mathrm{H}_{2} \mathrm{O}(2: 1)$ to afford ginsenoside $\mathrm{Rc}(13,35 \mathrm{mg})$, ginsenoside $\mathrm{Rb}_{2}(\mathbf{1 4}, 92 \mathrm{mg})$, and vinaginsenoside $\mathrm{R}_{4}(\mathbf{1 6}, 12$ $\mathrm{mg})$. Again, fr. $3.10(1.4 \mathrm{~g})$ was chromatographed on a RP column with $\mathrm{MeOH}-\mathrm{H}_{2} \mathrm{O}$ (3:1) to give ginsenoside $\mathrm{Re}(\mathbf{1 5}, 100$ $\mathrm{mg}$ ), ginsenoside $\mathrm{Mb}(\mathbf{1 7}, 14 \mathrm{mg})$, and ginsenoside $\mathrm{Rb}_{1}$ (18, $119 \mathrm{mg}$ ), respectively.

Fr. $1.6(15 \mathrm{~g})$ was subjected to a silica gel column with $\mathrm{CH}_{2} \mathrm{Cl}_{2}-\mathrm{MeOH}$ (15:1-1:1) to furnish seven subfractions (fr. $4.1 \sim$ fr. 4.7). Then, fr. 4.3 (2.6 g) was repeatedly chromatographed on a silica gel column with $\mathrm{CHCl}_{3}-\mathrm{MeOH}-\mathrm{H}_{2} \mathrm{O}(5: 1$ : 0.1 ), followed by a RP column with $\mathrm{MeOH}-\mathrm{H}_{2} \mathrm{O}$ (4:1) to afford ginsenoside $\mathrm{SF}(1,28 \mathrm{mg})$ and ginsenoside $\mathrm{Rs}_{4}(\mathbf{1 9}, 13 \mathrm{mg})$.

Ginsenoside SF(1): white amorphous powder; $[\alpha]_{\mathrm{D}}^{20}+18^{\circ}(c$ $0.22, \mathrm{MeOH}$ ); IR (KBr) $v_{\max } 3448,2922,1637,1262,1054 \mathrm{~cm}^{-1}$; ${ }^{1} \mathrm{H}-\mathrm{NMR}$ (pyridine- $d_{5}, 400 \mathrm{MHz}$ ) and ${ }^{13} \mathrm{C}-\mathrm{NMR}$ (pyridine- $d_{5}$, $100 \mathrm{MHz}$ ): see Table 1; HRESITOFMS $m / z 693.4141[\mathrm{M}+\mathrm{Na}]^{+}$ (Calcd for $\mathrm{C}_{36} \mathrm{H}_{62} \mathrm{O}_{11} \mathrm{Na}$ : 693.4190).

Acid hydrolysis and sugar determination of ginsenosides $\mathbf{S F}(1)$. A solution of the compound $(2.0 \mathrm{mg})$ in $1.0 \mathrm{M} \mathrm{HCl}(4.0$ $\mathrm{mL}$ ) was heated under reflux for $4 \mathrm{~h}$. Then, the reaction mixture was concentrated in vacuo to dryness. The residue was extracted with EtOAc and $\mathrm{H}_{2} \mathrm{O}(5 \mathrm{~mL}$ each, 3 times $)$. Next, the sugar residue, obtained by concentration of the water layer, was dissolved in dry pyridine $(0.1 \mathrm{~mL})$. Then L-cysteine methyl ester hydrochloride in pyridine $(0.06 \mathrm{M}, 0.1 \mathrm{~mL})$ was added to the solution. After heating the reaction mixture at $60{ }^{\circ} \mathrm{C}$ for $2 \mathrm{~h}$, $0.1 \mathrm{~mL}$ of trimethylsilylimidazole was added. Heating at $60^{\circ} \mathrm{C}$ was continued for a further $2 \mathrm{~h}$, and the mixture was evaporated in vacuo to give a dried product, which was partitioned between hexane and $\mathrm{H}_{2} \mathrm{O}{ }^{6}$. The hexane layer was analyzed by the GC procedure (General Procedures). The peak of the hydrolysate of 1 was detected at $t_{R} 14.12 \mathrm{~min}$ for D-glucose. The retention times for the authentic samples (Sigma), after being treated in the similar manner, were $14.12 \mathrm{~min}$ (D-glucose) and 14.25 $\min$ (L-glucose), respectively. Co-injection of the hydrolysates of the ginsenoside with standard D-glucose gave single peaks.

Acknowledgments. This study was supported by the Technology Development Program for Agriculture and Forestry (No. 108079-3), the Ministry for Agriculture, Forestry and Fisheries; and the Priority Research Center Program through the National Research Foundation of Korea (NRF) funded by the Ministry of Education, Science and Technology (2009- 
0093815), Republic of Korea. The authors thank the Korean Basic Science Institute (KBSI) for taking NMR and MS experiments.

\section{References}

1. Park, J. D.; Rhee, D. K.; Lee Y. H. Phytochem. Rev. 2005, 4, 159. 2. Shibata, S. J. Korean Med. Sci. 2001, 16, 28.

3. Yahara, S.; Kaji, K.; Tanaka, O. Chem. Pharm. Bull. 1979, 27, 88.

4. Yoshikawa, M.; Sugimoto, S.; Nakamura, S.; Sakumae, H.; Matsuda, H. Chem. Pharm. Bull. 2007, 55, 1034.

5. Sun, L. K.; Yoshii, Y.; Yamashiro, K.; Tomiyama, N.; Ishida, A.; Mukawa, J.; Jin, Y. R.; Wu, G. X. J. Brain Sci. 1999, 25, 63.

6. Tung, N. H.; Song, G. Y.; Park, Y. J.; Kim, Y. H. Chem. Pharm. Bull. 2009, 57, 1412.

7. Tung, N. H.; Song, G. Y.; Kim, J. A.; Hyun, J. H.; Kang, H. K.; Kim, Y. H. Bioorg. Med. Chem. Lett. 2010, 20, 309.

8. Park, I. H.; Kim, N. Y.; Han, S. B.; Kim, J. M.; Kwon, S. W.; Kim, H. J.; Park, M. K.; Park, J. H. Arch. Pharm. Res. 2002, 25, 428.

9. Ko, S. R.; Choi, K. J.; Suzuki, K.; Suzuki, Y. Chem. Pharm. Bull. 2003, 51, 404

10. Ryu, J. H.; Park, J. H.; Kim, T. H.; Sohn, D. H.; Kim, J. M.; Park,
J. H. Arch. Pharm. Res. 1996, 19, 335.

11. Yang, X. W.; Li, L. Y.; Tian, J. M.; Zhang, Z. W.; Ye, J. M.; Gu, W. F. Chin. Chem. Lett. 2000, 11, 909.

12. Ryu, J. H.; Park, J. H.; Eun, J. H.; Jung, J. H.; Sohn, D. H. Phytochemistry 1997, 44, 931.

13. Fujioka, N.; Kohda, H.; Yamasaki, K.; Kasai, R.; Shoyama, Y.; Nishioka, I. Phytochemistry 1989, 28, 1855.

14. Teng, R. W.; Ang, C. S.; McManus, D.; Armstrong, D.; Mau, S.; Bacic, A. Tetrahedron Lett. 2003, 44, 5661.

15. Bae, E. A.; Choo, M. K.; Park, E. K.; Park, S. Y.; Shin, H. Y.; Kim, D. H. Biol. Pharm. Bull. 2002, 25, 743.

16. Park, I. H.; Han, S. B.; Kim, J. M.; Piao, L.; Kwon, S. W.; Kim, N. Y.; Kang, T. L.; Park, M. K.; Park, J. H. Arch. Pharm. Res. 2002, 25, 837.

17. Zhao, P.; Liu, Y. Q.; Yang, C. R. Phytochemistry 1996, 41, 1419.

18. Teng, R. W.; Li, H. Z.; Chen, J. T.; Wang, D.; He, Y.; Yang, C. R. Magn. Reson. Chem. 2002, 40, 483.

19. Nakamura, S.; Sugimoto, S.; Matsuda, H.; Yoshikawa, M. Chem. Pharm. Bull. 2007, 55, 1342.

20. Takaku, T.; Kameda, K.; Matsuura, Y.; Sekiya, K.; Okuda, H. Planta Med. 1990, 56, 27.

21. Lee, S. D.; Okuda, H. Korean J. Ginseng Sci. 1990, 14, 67.

22. Do, J. H.; Lee, H. O.; Lee, S. K.; Noh, K. B.; Lee, S. D.; Lee, K. S. Korean J. Ginseng Sci. 1993, 17, 145. 